\title{
Penggunaan Algoritma Nearest Neighbor Pada Sistem Penalaran Berbasis Kasus Untuk Diagnosis Penyakit ISPA
}

\author{
Miswar Papuangan $^{1 *}$, Munazat Salmin ${ }^{2}$ \\ ${ }^{1}$ Prodi Teknik Informatika, Fakultas Teknik, Universitas Pasifik Morotai, Maluku Utara \\ ${ }^{2}$ Prodi Teknik Informatika, Fakultas Teknik, Universitas Khairun, Maluku Utara \\ *Koresponden email: miswarpapuangan@gmail.com
}

Diterima: 10 Desember 2019

Disetujui: 16 Desember 2019

\begin{abstract}
Acute Respiratory Infection is defined as an acute respiratory disease caused by an infectious agent that is transmitted from human to human. Symptoms include shortness of breath, difficulty breathing, sore throat, fever, wheezing, runny nose, and cough. This research implements CBR to help diagnose ARI. The diagnosis process is done by entering a new problem that contains the symptoms and risk factors that will be diagnosed in the system. The normalized nearest neighbor method with expert confidence is used to calculate the similarity between new problems and cases stored on a case basis. The results of testing the system using 112 case data with 78 case stored in a case base and 34 data used as new cases data, the system has identified four types of ARI disease with a system performance measurement $97.06 \%$.
\end{abstract}

Keywords: Case-Based Reasoning, Nearest Neighbor, Symptom, Risk Factor, ISPA

\begin{abstract}
Abstrak
Infeksi Saluran Pernapasan Akut merupakan penyakit saluran pernapasan akut yang disebabkan oleh agen infeksi yang ditularkan dari hubungan manusia dengan manusia. Munculnya tanda gejala biasanya sangat cepat hanya dalam waktu hitungan jam sampai beberapa hari. Gejala berupa sesak napas, kesulitan bernapas, nyeri tenggorokan, demam, mengi, pilek, dan batuk. Penelitian ini mengimplementasikan Penalaran Berbasis Kasus (PBK) untuk membantu melakukan diagnosis penyakit ISPA. Proses diagnosis dilakukan dengan cara memasukkan permasalahan baru yang berisi gejala-gejala dan faktor risiko yang akan didiagnosis ke dalam sistem PBK. Metode nearest neighbor yang dinormalisasi dengan tingkat keyakinan pakar digunakan untuk menghitung kesamaan antara permasalahan baru dengan kasus yang tersimpan dalam basis kasus. Hasil pengujian sistem dengan menggunakan 112 data kasus dengan 78 kasus yang tersimpan dalam basis kasus dan 34 data dijadikan sebagai data kasus baru, sistem telah mengidentifikasi empat macam penyakit ISPA dengan pengukuran unjuk kerja sistem $97,06 \%$.
\end{abstract}

Kata Kunci: Penalaran Berbasis Kasus, Nearest Neighbor, Gejala, Faktor Resiko, ISPA

\section{Pendahuluan}

Peyakit Infeksi Saluran Pernapasan Akut atau yang lebih dikenal dengan sebutan ISPA merupakan penyakit saluran pernapasan pada bagian atas ataupun bagian bawah dan menular, yang dapat menimbulkan berbagai spektrum penyakit yang berkisar tanpa gejala atau biasanya infeksi ringan sampai pada penyakit parah sampai mematikan, yang tergantung pada patogen penyebabnya, yakni disebabkan karena faktor lingkungan, faktor hubungan manusia dengan manusia. Timbulnya gejala biasanya sangat cepat, baik dalam hitungan jam sampai pada beberapa hari. Gejala berupa sesak napas, nyeri tenggorokan, pilek, mengi, demam, kesulitan bernapas, dan batuk [1].

Infeksi virus akut biasanya menular pada penyakit epidermis musiman atau influenza musiman, penyakit influenza pandemik, yang ditandai dengan radang pada saluran pernapasan, biasanya ditunjukan dengan adanya demam secara mendadak, menggigil, merasa sangat letih, nyeri otot, nyeri tenggorokan, batuk, dan pilek [2]. Data Riset Kesehatan Dasar menunjukan jenis penyakit pneumonia menduduki pada peringkat kedua sebagai penyakit mematikan pada anak usia bayi $(23,8 \%)$ dan usia balita $(15,5 \%)$, dengan diilustrasikan periode prevalensi dan prevalens dari pneumonia $(1,8 \%)$ dan $(4,5 \%)$. Sedangkan menurut data laporan rutin Subdit ISPA, terdapat insiden per 1000 anak dengan usia balita di Indonesia sebesar $20,54 \%$ [2].

Hasil penelitian penyakit ISPA yang dilakukan oleh [3] menunjukan akurasi sebesar 88,57\%. Sedangkan hasil penelitian yang dilakukan oleh [4] menggunakan algoritma k-nearest neighboar menunjukan akurasi sebesar 94,29\%. 
Seorang dokter dalam mendiagnosa pasien penderita penyakit ISPA, maka perlu diketahui tandatanda gejala dan faktor resiko yang di rasakan maupun yang dialami oleh pasien. Kemunculan suatu gejala dan faktor resiko pada pasien hampir sama dengan berbagai macam jenis penyakit ISPA, ini perlu perhatian serius dari dokter atau dokter spesialis untuk melakukan tindakan dalam mengambil suatu keputusan diognosa pasien. Dengan keterbatasan kesediaan dokter spesialis dapat mengakibatkan lambatnya penanganan dalam mengatasi masalah diagnosa penyakit pasien, maka perlu adanya kebutuhan suatu alat bantu yang dapat membantu dan mengatasi untuk mendiagnosa pasien penderita jenis penyakit ISPA.

Terdapat banyak metode yang digunakan untuk merancang dan membangun suatu sistem diantaranya dengan menggunakan kecerdasan buatan yaitu sistem penalaran berbasis kasus. Cara kerja penalaran berbasis kasus yakni menggunakan pengetahuan lama untuk memecahkan suatu permasalahan baru dengan cara mengukur kesamaan antara kasus baru dengan kasus yang disimpan dibasis kasus. Kelebihan yang ditawarkan menggunakan metode ini adalah akuisisi dan manajemen pengetahuan yang mudah dilakukan, dapat melakukan incremental learning, bersifat fleksibel dan adaptif.

Penelitian ini menerapkan sebuah sistem penalaran berbasis kasus untuk diagnosis penyakit ISPA dengan pengukuran similaritas menggunakan algoritma nearest neighbor yang dinormalisasikan dengan tingkat keyakinan pakar. Salah satu sistem yang dibangun untuk membantu mendiognosa pasien penderita jenis penyakit ISPA dengan maksud sebagai alat bantu untuk membantu dokter spesialis untuk melakukan diagnosa dalam melayani pasien dengan cepat dan tepat.

\section{Tinjauan Pustaka}

\subsection{Penalaran Berbasis Kasus}

Penalaran berbasis kasus adalah suatu sistem yang digunakan untuk memecahkan permasalahan baru, dengan mengadaptasi solusi yang digunakan untuk memecahkan masalah lama[5]. Penyelesaian masalah dilakukan dengan metodologi untuk penalaran dan belajar. Cara kerja PBK dilakukan dengan cara penalaran dalam mengukur kesamaan kasus baru dengan kasus yang tersimpan dalam basis kasus selama terdapat kemiripan diantara keduanya [6]. Namun apabila dalam melakukan pengujian kesamaan dengan mencari kasus yang tersimpan di basis kasus dan tidak ditemukan, maka sistem PBK akan melakukan suatu teknik yang dinamakan teknik adaptasi dengan cara memasukkan kasus tersebut ke dalam basis kasus untuk disimpan dan kemudian dilakukan revisi oleh pakar untuk mendapatkan solusi atas kasus tersebut. Terdapat empat sub proses sistem penalaran berbasis kasus [7].

1. Retrieval: Ide dasar dari teknik ini adalah membandingkan setiap fitur target kasus dengan fitur-fitur yang tersimpan pada basis basus, kemudian perbandingan tersebut dihitung dengan menggunakan fungsi similaritas.

2. Reuse : Dari hasil proses retrieval tidak diperoleh kasus yang sama, maka solusi yang disarankan oleh sistem adalah solusi kasus terdahulu yang mempunyai nilai similaritas tertinggi.

3. Revise : Revise merupakan bagian dari adaptasi sistem terhadap kasus yang belum berhasil didiagnosa. Permasalahan baru yang tidak diperoleh kasus yang sama atau tidak memiliki nilai similaritas tertinggi, maka solusi yang disarankan adalah menyerahkan kasus tersebut kepada pakar untuk kemudian dilakukan perbaikan kesalahan.

4. Retain: Sebuah permasalahan baru diselesaikan dengan mencari sebuah kasus lama yang identik, jika ditemukan maka solusi keduanya juga identik. Solusi kasus baru tersebut kemudian divalidasi oleh pakar dan disimpan sebagai pengalaman yang nantinya berguna untuk pemecahan permasalahan baru.

\subsection{Infeksi Saluran Pernapasan Akut}

Infeksi Saluran Pernapasan Akut merupakan infeksi saluran pernapasan atas maupun pernapasan bawah yang menjadi faktor penyebabnya adalah infeksi virus, radang parenkim paru, dan bakteri[8]. ISPA masih menjadi salah satu penyakit endemik dan menjadi masalah kesehatan yang dialami masyarakat karena merupakan penyakit akut dan menyebabkan kematian yang lebih rentan pada anak usia balita yang terjadi diberbagai negara berkembang termasuk di Indonesia. Sehiggga sangat penting untuk diperhatikan pemerintah dalam menangani masalah penyakit ISPA [9]. Infeksi Saluran Pernapasan Akut dapat berlangsung selama 2 minggu bahkan lebih yang ditularkan melalui polusi udara, darah, pernapasan maupun bersin yang terindikasi kuman, dan bisa juga melalui darah. ISPA ditandai dengan gejala seperti demam, batuk, pilek, sakit kepala, sakit tenggorokan, anoreksia, muntah, nausea, dan lendir menjadi kental [8]. Data World Health Organization (WHO) menunjukan penyakit ISPA yang paling sering diderita oleh anak usia balita $(78 \%)$. Terdapat kasus penyakit ISPA berat (56\%) laki-laki dan (44\%) merupakan perempuan [1]. 


\section{Metode Penelitian}

\subsection{Representasi Kasus}

Penalaran berbasis kasus tergantung pada struktur dan isi koleksi kasus. Suatu kasus dapat diselesaikan dengan memanggil kasus terdahulu yang sesuai dengan dengan kasus baru. Suatu kasus merupakan bagian dikontekstualisasi pengetahuan mewakili pengalaman [10].

Representasi sebuah kasus dalam domain medis untuk kepentingan diagnosis penyakit, lazimnya terbagi menjadi tiga bagian yaitu identitas pasien, kondisi pasien sebagai permasalahan, dan solusi dalam bentuk diagnosis [5]. Kasus dapat direpresentasikan dalam berbagai bentuk, seperti representasi preposisional, frame, jaringan semantik. Berikut salah satu model representasi kasus yang digunakan dalam bentuk frame sebagaimana diperlihatkan pada Tabel 1.

Tabel 1. Jenis dan penilaian atribut

\begin{tabular}{ll}
\hline \multicolumn{1}{c}{ Atribut } & \multicolumn{1}{c}{ Nilai } \\
\hline Usia & Dalam satuan tahun \\
Jenis kelamin & Laki-laki = 1 dan Perempuan =0 \\
Gejala dan faktor risiko & Ya =1 dan Tidak =0 \\
Tingkat keyakinan & Range 0 - 100 (dalam satuan persen) \\
Diagnosis & Faringitis \\
& Bronkitis \\
& Influenza \\
& Pneumonia \\
\hline
\end{tabular}

Data identitas pasien dirahasiakan dalam merepresentasi sebuah kasus ke dalam sistem PBR. Permasalahan dalam penelitian ini direpresentasikan melalui beberapa fitur yaitu usia, jenis kelamin, gejala, dan faktor risiko. Sedangkan solution space-nya meliputi Faringitis, Bronkitis, Influenza, dan Pneumonia.

\subsection{Teknik Retrieve}

Teknik retrieve digunakan untuk mencari kasus terhahulu yang indentik dengan kasus baru menggunakan algoritma nearest neighbor. Algoritma nearest neighbor digunakan untuk menghitung kemiripan antara permasalahan kasus baru dengan kasus yang tersimpan dalam basis kasus dengan membandingkan setiap fitur-fitur yang ada pada suatu kasus.

Fitur-fitur tiap kasus ditentukan oleh pakar yang mempunyai bobot nilai berbeda satu sama lainnya, sebagaimana ditunjukkan pada Tabel 2.

Tabel 2. Bobot atribut

\begin{tabular}{|c|c|c|c|c|}
\hline Atribut & Faringitis & Bronkitis & Influenza & Pneumonia \\
\hline Usia & 5 & 5 & 5 & 5 \\
\hline Jenis kelamin & 5 & 5 & 5 & 5 \\
\hline Demam & 2 & 2 & 1 & 3 \\
\hline Nyeri menelan & 2 & 2 & 1 & 2 \\
\hline Sakit kepala & 4 & 4 & 3 & 5 \\
\hline Pilek & 1 & 1 & 1 & 1 \\
\hline Mual & 1 & 1 & 1 & 2 \\
\hline Amandel & 4 & 4 & 2 & 6 \\
\hline Batuk & 2 & 2 & 1 & 3 \\
\hline Gelisah & 1 & 1 & 1 & 1 \\
\hline Malaise/lemas & 2 & 1 & 1 & 2 \\
\hline Anoreksia/gangguan makan & 1 & 1 & 1 & 1 \\
\hline Nyeri otot & 2 & 2 & 1 & 2 \\
\hline Tachypnea/nafas cepat & 2 & 2 & 2 & 2 \\
\hline Dyspnea/sesak nafas & 5 & 6 & 3 & 7 \\
\hline Nyeri sendi & 3 & 3 & 2 & 5 \\
\hline Berdahak & 4 & 4 & 2 & 4 \\
\hline Gemetar, mengigil dan kejang & 3 & 3 & 3 & 3 \\
\hline Suara serak & 1 & 1 & 1 & 1 \\
\hline
\end{tabular}


Detak jantung cepat

Diare

Muntah

Pusing

Sakit perut

Gatal-gatal/bintik merah

Gangguan penglihatan

Nyeri dinding dada

Afebris/demam tetapi tidak

menunjukan tanda-tanda

demam

Tidak bisa tidur

Berkeringat

Nyeri ulu hati

Nyeri telinga

Merokok

Asma

Infeksi

Minuman keras

Riwayat penyakit

Hipotermia

Stress

Volume cairan

$\begin{array}{cccc}2 & 2 & 2 & 2 \\ 2 & 2 & 1 & 2 \\ 4 & 4 & 2 & 3 \\ 2 & 2 & 2 & 2 \\ 5 & 5 & 5 & 5 \\ 4 & 4 & 4 & 4 \\ 6 & 6 & 6 & 8 \\ 8 & 7 & 6 & 10\end{array}$

1

$$
1
$$

1

1

$\begin{array}{llll}1 & 1 & 1 & 1\end{array}$

$\begin{array}{llll}1 & 1 & 1 & 1\end{array}$

$\begin{array}{llll}7 & 6 & 5 & 9\end{array}$

$\begin{array}{llll}4 & 3 & 2 & 5\end{array}$

$\begin{array}{llll}5 & 6 & 5 & 7\end{array}$

$\begin{array}{llll}8 & 8 & 5 & 8\end{array}$

$\begin{array}{llll}8 & 8 & 5 & 8 \\ 3 & 3 & 2 & 3\end{array}$

$\begin{array}{llll}6 & 6 & 4 & 7\end{array}$

$\begin{array}{llll}5 & 5 & 3 & 6\end{array}$

$5 \quad 5 \quad 3 \quad 6$

$\begin{array}{llll}2 & 2 & 2 & 2\end{array}$

$3 \quad 3 \quad 3 \quad 5$

\section{Similaritas Lokal}

Pengukuran similaritas akan menghasilkan nilai yang menentukan tentang ada atau tidak kemiripan antara kasus baru dengan kasus yang tersimpan dalam basis kasus. Suatu kasus dikatakan identik dengan kasu baru apabila nilai similaritas sama dengan 1, jika dikatakan mirip jika nilai similaritasnya dibawah 1 . Pengukuran similaritas lokal diasumsikan bahwa seluruh data yang ada dalam basis kasus memiliki atribut yang bernilai sama (sudah diseleksi). Untuk menghitung fungsi similaritas lokal tipe data numerik menggunakan persamaan (1) [11]. Dimana $s, t$ merupakan nilai tiap fitur yang akan dibandingkan sedangkan $R$ merupakan range nilai fitur tersebut dan untuk tipe data Boolean, fungsi similaritas lokal berlaku persamaan (2) [11].

$$
\begin{gathered}
f(s, t)=1-\frac{|s-t|}{R} \\
f(s, t)=\left\{\begin{array}{l}
1 \text { jika } s=t \\
0 \text { jika } s \neq t
\end{array}\right.
\end{gathered}
$$

\section{Pengukuran Tingkat Keyakinan}

Untuk menghitung tingkat keyakinan bahwa suatu permasalahan baru yang disimbolkan dengan $T$ merupakan bagian dari basis kasus yang disimbolkan dengan $S$. Untuk menghitung tingkat keyakinan pada permasalahan baru menggunakan persamaan (3) [12].

Keterangan :

$$
\mu(S, T)=\frac{J\left(S_{\left.i, T_{i}\right)}\right.}{J\left(T_{i}\right)}
$$

$\mu(S, T) \quad$ : tingkat keyakinan terhadap permasalahan baru $T$ yang indentik dengan basis kasus $S$

$J\left(S_{i}, T_{i}\right) \quad$ : banyaknya fitur atribut permasalahan baru $T$ yang indentik dengan basis kasus $S$

$J\left(T_{i}\right) \quad$ : banyaknya fitur atribut yang muncul pada permasalahan baru 


\section{Similaritas Global}

Metode untuk menghitung bobot kemiripan pada similaritas global yakni dengan menggunakan algoritma nearest neighbor. Similaritas global digunakan untuk menghitung tingkat kemiripaan antara permasalahan baru dengan kasus-kasus yang disimpan pada basis kasus, dengan menggunakan persamaan (4) [13].

$$
\operatorname{SimNN}(S, T)=\frac{\sum_{i=1}^{n} f\left(S_{\left.i, T_{i}\right) *\left(W_{i}\right)}\right.}{\sum_{i=1}^{n} W_{i}}
$$

Keterangan :

$\operatorname{SimNN}(S, T) \quad$ : similaritas global antara basis kasus $(S)$ dengan permasalahan baru $(T)$

$T \quad$ : permasalahan baru

$S \quad$ : kasus yang tersimpan dalam basis kasus

$n \quad$ : banyaknya fitur atribut dalam setiap kasus

$i \quad$ : fitur atribut individu antara 1 sampai dengan fitur $n$

$f\left(S_{i}, T_{i}\right)$ : fungsi similaritas lokal fitur atribut ke- $i$ antara basis kasus $S$ dan permasalahan baru $T$

$W_{i} \quad$ : bobot nilai yang diberikan pada tiap atribut ke- $i$

Mengingat pentingnya tingkat keyakinan pakar terhadap setiap kasus, maka perlu dilakukan perubahan. Perubahan dilakukan untuk menangani permasalahan yang serupa, dengan menambah tingkat keyakinan pada persamaan (3) dengan persamaan (4) ke dalam perhitungan similaritas kasus sebagaimana ditunjukan oleh persamaan (5).

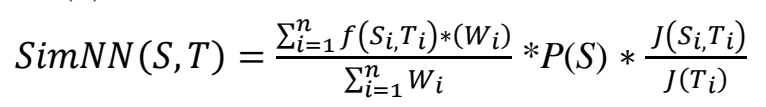

Keterangan:

$\operatorname{SimNN}(S, T) \quad$ : similaritas global antara basis kasus $S$ dengan permasalahan baru $T$

$f\left(S_{i}, T_{i}\right)$ : fungsi similaritas lokal fitur atribut ke- $i$ antar basis kasus $S$ dengan permasalahan baru $T$

$n$ : banyaknya fitur atribut dalam setiap kasus

$S_{i} \quad$ : atribut ke- $i$ dari basis kasus

$T_{i} \quad:$ atribut ke- $i$ dari permasalahan baru

$W_{i} \quad$ : bobot nilai yang diberikan pada atribut ke- $i$ pada penyakit dari basis kasus

$P(S)$ : persentase tingkat keyakinan pakar terhadap tiap kasus di basis kasus

$J\left(S_{i}, T_{i}\right)$ : banyaknya fitur atribut permasalahan baru $T$ yang identik dengan kasus di basis kasus $S$

$J\left(T_{i}\right) \quad$ : banyaknya fitur atribut yang muncul pada permasalahan baru.

\subsection{Proses Adaptasi}

Kasus-kasus hasil retrieval merupakan kasus terdahulu yang identik dengan masalah kasus baru, maka solusi dari kasus terhadulu dapat digunakan kembali oleh masalah kasus baru. Namun terkadang tidak semua kondisi permasalahan baru sama dengan kasus terdahulu, maka solusi dari permasalahan baru perlu diubah agar sesuai dengan kondisi yang sebenarnya. Proses ini disebut proses adaptasi. Berikut terdapat beberapa teknik yang digunakan untuk melakukan proses adaptasi [5].

1. Null Adaptation

2. Pengaturan parameter

3. Reinstantiation

4. Derivation replay

5. Perbaikan model terpadu.

Teknik adaptasi yang digunakan adalah dengan menentukan nilai threshold. Jika similaritas tertinggi memiliki nilai atas threshold $(\geq 80 \%)$ maka solusi dari kasus yang mempunyai nilai similaritas tertinggi dipilih sebagai solusi permasalahan kasus baru. Sedangkan jika kurang dari $80 \%$ maka akan disimpan untuk mendapatkan revisi dari pakar.

\subsection{Deskripsi Sistem}

Sistem yang dibangun digunakan untuk melakukan diagnosis penyakit ISPA dengan mengimplementasikan konsep penalaran berbasis kasus. Algoritma nearest neighbor yang mengakomodasi tingkat keyakinan digunakan untuk mencari nilai kemiripan antara kasus terdahulu dengan permasalahan baru pada saat dilakukan proses retrieval. Secara garis besar deskripsi sistem ditunjukan pada Gambar 1. 


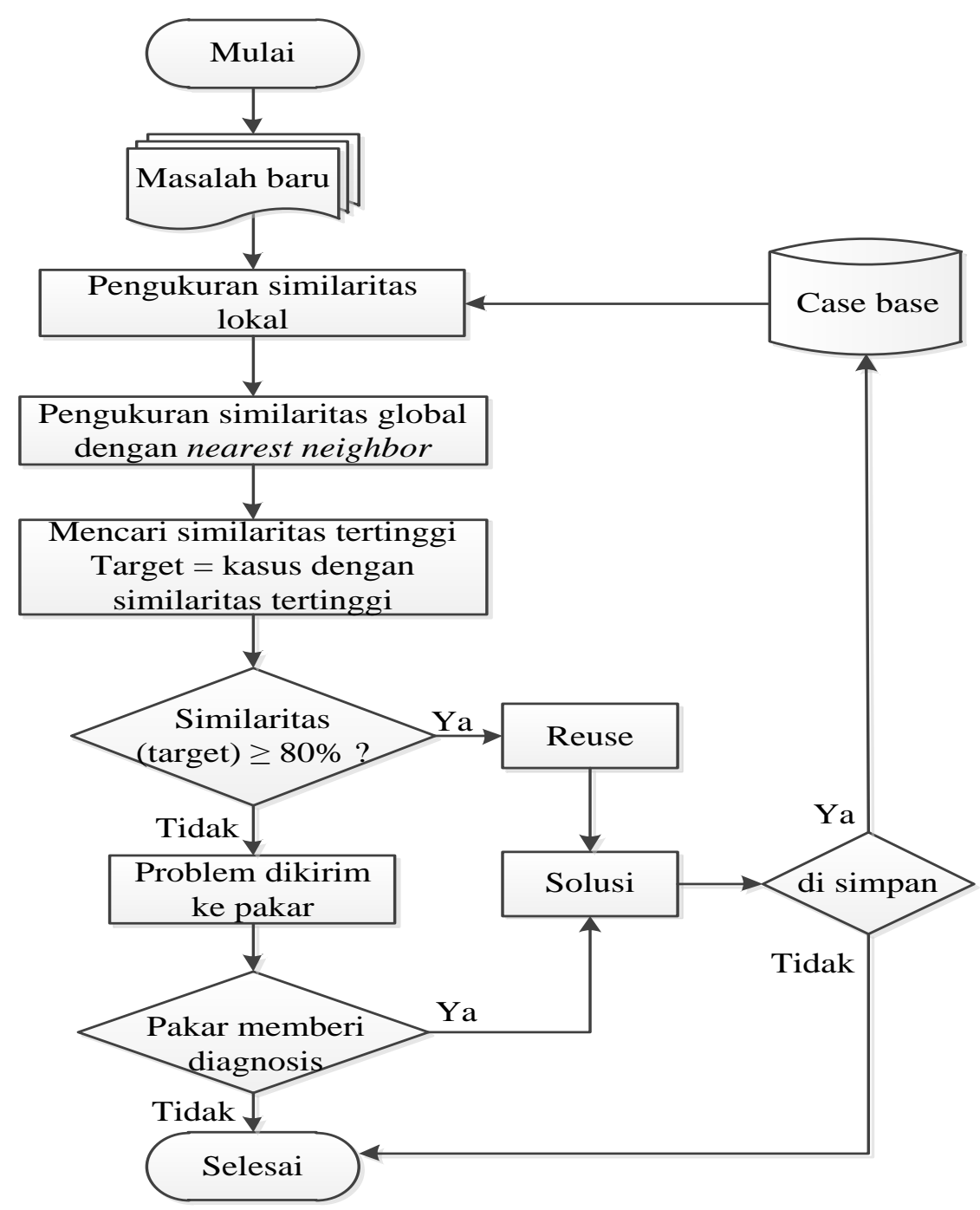

Gambar 1. Diagram alir sistem PBK untuk diagnosa penyakit ISPA

\subsection{Pengujian Sistem}

Pengujian sistem dilakukan dengan melakukan pengukuran terhadap data yang diujikan. Pengukuran akurasi dihitung dengan membandingkan jumlah diagnosis benar oleh sistem dengan jumlah data uji. Perbandingan dapat dituliskan dalam bentuk persamaan (6) [14].

$$
\text { Akurasi }=\frac{\sum \text { diagnosa benar }}{\sum \text { data uji }} \times 100 \%
$$

\subsection{Diagram Konteks}

Diagram konteks merupakan level tertinggi dari data flow diagram yang menggambarkan suatu sistem yang dibangun dengan dokumen input dan output serta entitas-entitas yang berhubungan dengan sistem yang dibangun. Sistem yang dibangun yakni sistem PBK untuk diagnosa penyakit ISPA terdapat tiga entitas pengguna sistem, yakni admin, pakar, dan paramedis. Diagram konteks sistem PBK untuk diagnosa peyakit ISPA ditunjukan pada Gambar 2. 


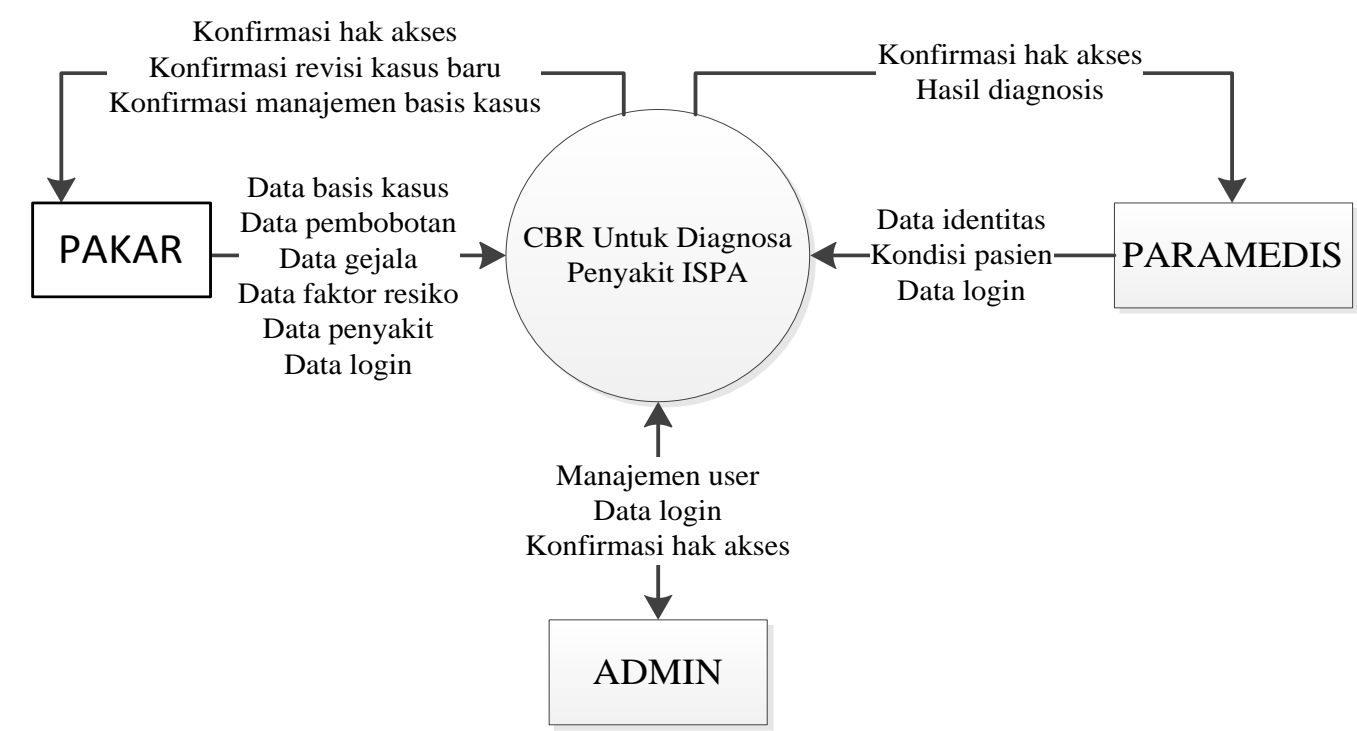

Gambar 2. Diagram konteks sistem PBK untuk diagnosa Penyakit ISPA

Pada Gambar 2 menunjukan bahwa pakar menginput data-data ke dalam sistem PBK berupa usia, jenis kelamin, gejala, faktor resiko, data penyakit, dan data nilai pembobotan ke dalam basis kasus. Selain data-data tersebut, pakar juga melakukan revisi terhadap sebuah permasahan baru. Sistem akan memberikan notifikasi ke pakar apabila terdapat kasus yang memerlukan revisi. Seorang paramedis menginput data berupa identitas pasien dan kondisi yang dirasakan maupun dialami pasien yakni gejala dan faktor resiko. Setelah paramedis melakukan proses diagnosa, sistem akan menampilkan hasil diagnosis ke paramedis untuk kemudian diberikan ke pasien atau bisa juga disimpan hasil diagnosis permasalahan baru tersebut ke dalam sistem. Sedangkan admin merupakan user yang berhubungan dengan tata kelola pengguna sistem.

\subsection{Rancangan Arsitektur Sistem}

Sistem dirancang untuk dapat melakukan diagnosis penyakit ISPA. Proses diagnosis dilakukan dengan cara menginput data-data pasien ke dalam sistem oleh pakar, paramedis, dan admin. Arsitektur sistem yang dibangun secara umum ditunjukan oleh Gambar 3.

Pada Gambar 3 menunjukan bagaimana proses dari suatu sistem PBR yang dibangun. Tahap awal paramedis melakukan penginputan permasalahan baru berupa data-data pasien yakni data usia, jenis kelamin, gejala, dan faktor resiko ke dalam sistem PBK menggunakan modul input data yang dikembangkan melalui GUI (Graphical User Interface). Kemiripan permasalahan baru dengan kasus terdahulu yang disimpan di basis kasus dihitung dengan menggunakan algoritma nearest neighbor. Jika kasus terdahulu mempunyai nilai similaritas tertinggi, maka selanjutnya dipilih untuk dijadikan kandidat solusi dari permasalahan baru yang diinputkan tersebut. Kandidiat solusi yang mempunyai nilai similaritas $\geq 80 \%$ maka solusi tersebut diambil sebagai solusi permasalahan. Sedangkan jika mempunyai nilai similaritas $<80 \%$, maka permasalahan tersebut disimpan untuk kemudian dilakukan revisi oleh pakar. Dari solusi hasil proses diagnosis yang dilakukan kemudian di sampaikan kepada user melalui modul output untuk diberikan kepada pasien. 


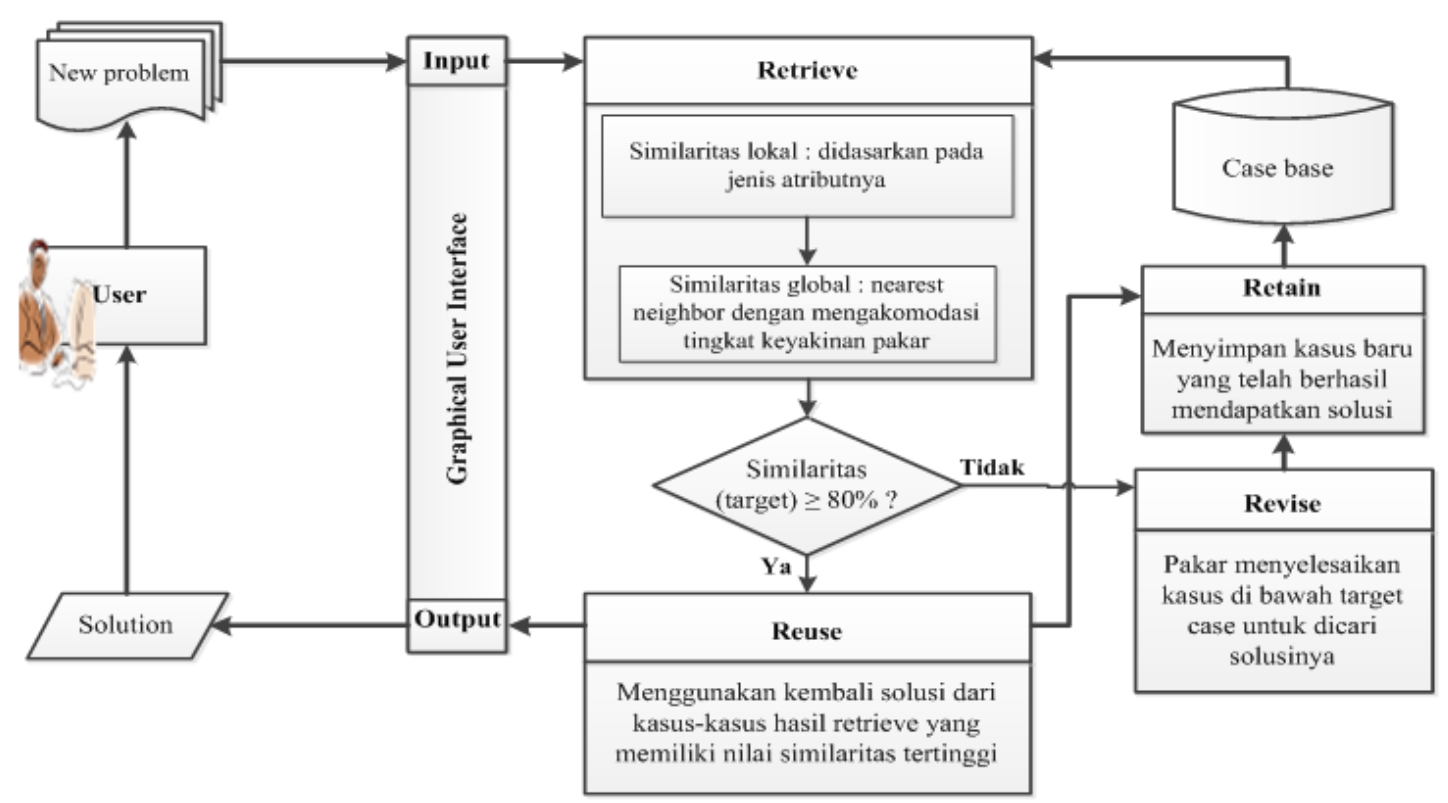

Gambar 3. Arsitektur sistem PBK untuk diagnosis penyakit ISPA

\subsection{Data dan Metode Pengujian}

Data yang digunakan yaitu data pasien penderita penyakit ISPA. Jumlah data kasus yang digunakan untuk menyusun basis kasus sebanyak78 data kasus atau $70 \%$ dari total data penderita penyakit ISPA yang diperoleh (112 data kasus). Tabel 3 memperlihatkan rincian data pasien penderita penyakit ISPA yang digunakan.

Tabel 3. Jumlah data basis kasus pasien penderita jenis penyakit ISPA

\begin{tabular}{cccc}
\hline No & Jenis Penyakit ISPA & Jumlah Data Kasus & Data Basis Kasus \\
\hline 1. & Faringitis & 36 & 25 \\
2. & Bronkitis & 40 & 28 \\
3. & Influenza & 9 & 6 \\
4. & Pneumonia & 27 & 19 \\
\hline & Total & 112 & 78 \\
\hline
\end{tabular}

Sebanyak 34 kasus atau 30\% dari total keseluruhan data pasien penderita penyakit ISPA digunakan sebagai data uji. Rincian data uji ditunjukkan pada Tabel 4.

Tabel 4. Jumlah data uji yang digunakan

\begin{tabular}{cccc}
\hline No & Jenis Penyakit ISPA & Jumlah Data Kasus & Data Uji \\
\hline 1. & Faringitis & 36 & 11 \\
2. & Bronkitis & 40 & 12 \\
3. & Influenza & 9 & 3 \\
4. & Pneumonia & 27 & 8 \\
\hline & Total & 112 & 34 \\
\hline
\end{tabular}

Evaluasi hasil pengujian sistem dalam mendignosis penyakit ISPA dilakukan dengan cara menghitung tingkat akurasi.

\section{Hasil dan Pembahasan}

Pengujian dilakukan dengan cara mengukur hasil diagnosis benar oleh sistem yang dibangun dengan diagnosis permasalahan baru. Hasil pengujian dari keseluruhan data uji yang telah dilakukan, maka didapat dua permasalahan yang mempunyai nilai similaritas di bawah batas nilai threshold yang ditetapkan sehingga tidak dapat diklasifikan ke dalam jenis penyakit ISPA.

Pengukuran akurasi secara keseluruhan dapat membantu untuk mengetahui dan melihat rincian kinerja sistem yang dibangun, yakni seberapa kelas $X$ secara benar yang diklasifikasikan sebagai kelas $X$ 
dan kesalahan diklasifikasikan sebagai kelas yang lain. Informasi ini disajikan dalam Confusion Matrix [15].

Rekapitulasi hasil pengujian untuk setiap kombinasi diperlihatkan pada Tabel 5 dan diilustrasikan dalam bentuk grafik oleh Gambar 3. Sumbu horisontal menunjukkan jenis penyakit ISPA dan sumbu vertikal menunjukkan jumlah diagnosis benar sesuai jenisnya.

Tabel 5. Confusion matrix hasil pengujian

\begin{tabular}{lccccc}
\hline & & \multicolumn{4}{c}{$\begin{array}{c}\text { Predicted class } \\
\text { (hasil pengujian sistem) }\end{array}$} \\
\cline { 3 - 6 } & & Faringitis & Bronkitis & Influenza & Pneumonia \\
\multirow{4}{*}{ Actual } & Faringitis & 11 & 0 & 0 & 0 \\
& Bronkitis & 1 & 11 & 0 & 0 \\
& Influenza & 0 & 0 & 3 & 0 \\
& Pneumonia & 0 & 0 & 0 & 8 \\
\hline
\end{tabular}

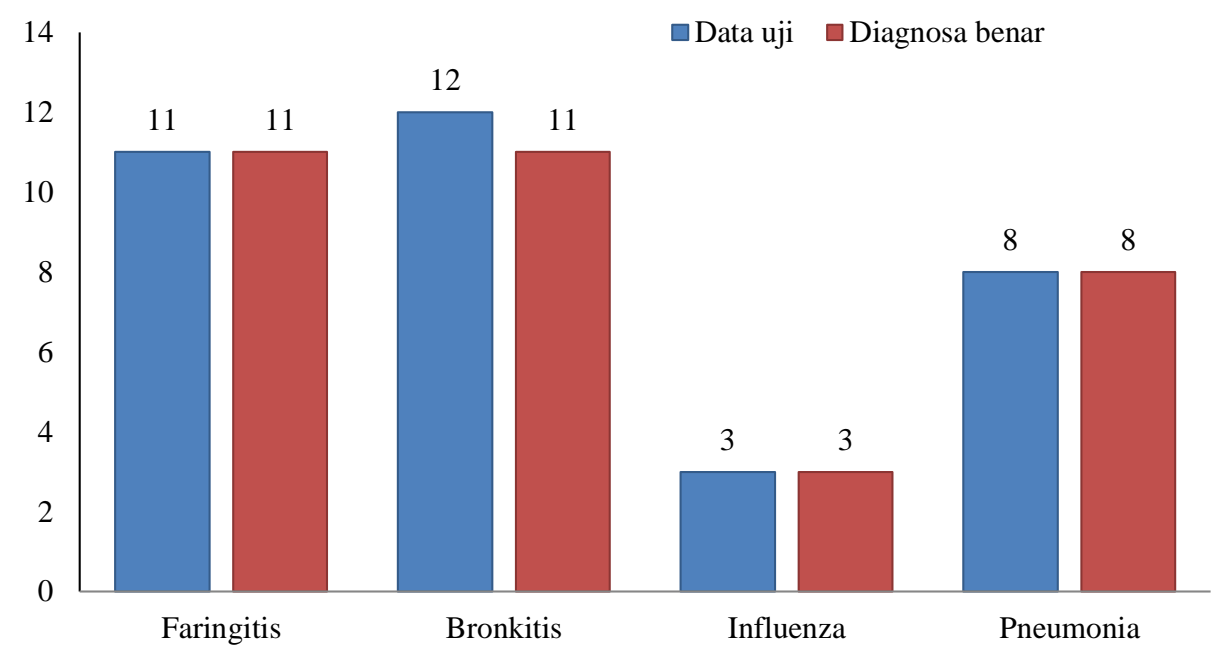

Gambar 3. Grafik hasil pengujian yang dilakukan

Perhitungan akurasi akan menunjukan persentase unjuk kerja sistem yang dibangun dalam mengenali jenis penyakit ISPA secara benar. Unjuk kerja sistem hitung dengan menggunakan persamaan (6).

$$
\text { Akurasi }=\frac{33}{33+1} \times 100 \%=97,06 \%
$$

\section{Kesimpulan}

Dari hasil pengujian yang telah dilakukan, maka dapat disimpulkan bahwa sistem penalaran berbasis kasus yang telah dirancang dan dibangun untuk mendiagnosis penyakit ISPA dengan pengukuran similaritas menggunakan algoritma nearest neighbor dengan nilai threshold $80 \%$, sistem memiliki unjuk kerja dengan tingkat akurasi sebesar 97,06\%

\section{Daftar Pustaka}

[1] World Health Organization (WHO), 2018. Pencegahan dan Pengendalian Infeksi Saluran Pernapasan Akut (ISPA) Yang Cenderung Menjadi Epidemi dan Pandemi, Trust Indonesia Partner in Development.

[2] Kemenkes RI. 2007, Profil Kesehatan Indonesia, Health Statistics, Kementerian Kesehatan Republik Indonesia, Jakarta.

[3] Salmin, M., dan Hartati, S., 2018, Case Based Reasoning Untuk Diagnosis Penyakit Infeksi Saluran Pernapaan Akut. Jurnal Informatika dan komputer (JIKO), 1, 1, 21-26. 
[4] Papuangan, M., 2018, Penerapan Case Based Reasoning Untuk Sistem Diagnosis Penyakit Hepatitis. Jurnal Informatika dan Komputer (JIKO), 1, 1, 7-12.

[5] Pal, S.K., dan Shiu, S.C.K., 2004, Foundation of Soft Case-Based Reasoning, John Willey and Sons, Inc., New Jersey.

[6] Rismawati, T., dan Hartati, S., 2012, Case Based Reasoning Untuk Diagnosa Penyakit THT (Telinga Hidung dan Tenggorokan). IJCCS, 1, 1, 67-78.

[7] Aamodt, A., dan Plaza, E., 1994, Case Based Reasoning. Foundational Issues, Methodological Variations, and System Approaches, AI Communication IOS Press, 7, 1, 39-59

[8] Wijayaningsih, K.S., 2013, Standar Asuhan Keperawatan. TIM, Jakarta.

[9] Kemenkes RI, 2013. Riset Kesehatan Dasar; RISKESDA, Balitbang Kementerian Kesehatan Republik Indonesia, Jakarta.

[10] Delany, S, J.,2006, Using Case-Based Reasoning for Spam Filtering. Tesis, Dublin Institute of Technology. Dublin. Irlandia.

[11] Jha, M.K., Pakhira, D., dan Chakraborty, B., 2013. Diabetes Detection and Care Applying CBR Technuquez, IJSC, 6, 2, 132-137

[12] Nurdiansyah, Y., dan Hartati, S., 2014, Case Based Reasoning Untuk Pendukung Diognosa Gangguan Pada Anak Autis, Tesis, Prodi S2/S3 Ilmu Komputer, Universitas Gadjah Mada, Yogyakarta.

[13] Ong, L., S., Shepherd, B., Tong, L. C., Choen, F.S., Ho, H.K., Tang. C.L., Ho. Y.S., dan Tan. K., 1997. The Colortecal Cancer Reccurence Support (CARES) System Artificial Intelligence in Medicine Elsevier, vol 11, 175-188.

[14] Witten, I.H., dan Frank, E., 2005. Data Mining : Practical Machine Learning Tools and Techniquez, 2, Morgan Kaufmann Publisher, San Fransisco.

[15] Bramer, M., 2007, Principles of Data Mining, Springer-Verleg, London. 